\title{
Isolation, identification and diesel-oil biodegradation capacities of indigenous hydrocarbon-degrading strains of Cellulosimicrobium cellulans and Acinetobacter baumannii from tarball at Terengganu beach, Malaysia
}

\begin{abstract}
In this study, we isolated two indigenous hydrocarbon-degrading bacteria from tarball found in Rhu Sepuluh beach, Terengganu, Malaysia. These bacteria were identified based on their physiological characteristic and 16S rRNA gene sequence analysis, and they showed 99\% similarity with Cellulosimicrobium cellulans DSM 43879 and Acinetobacter baumannii ATCC 19606 respectively. Their hydrocarbon-degrading capabilities were tested using diesel-oil as sole carbon source. Results analysed using GC-MS, showed diesel-oil alkanes were degraded an average $64.4 \%$ by C. cellulans and $58.1 \%$ by A. baumannii with medium optical density reaching 0.967 (C. cellulans) and 1.515 (A. baumannii) in minimal salt media at $32{ }^{\circ} \mathrm{C}$ for 10 days. Individual diesel-oil alkanes were degraded between $10 \%-95.4 \%$ by $\mathrm{C}$. cellulans and $0.2 \%-95.9 \%$ by A. baumannii. Both strains utilized diesel-oil for growth. The study suggests both strains are part of indigenous hydrocarbon-degrading bacteria in tarball with potential for bioremediation of oil-polluted marine environment.
\end{abstract}

Keyword: Acinetobacter baumannii; Bioremediation; Cellulosimicrobium cellulans; Dieseloil; Hydrocarbons; Tarball 